Preface

\title{
Cretaceous Earth Dynamics and Climate in Asia
}

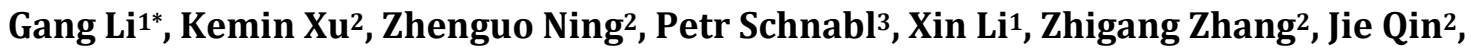 \\ Yongbo Huang ${ }^{2}$, Jing Guo ${ }^{2}$
}

\author{
${ }^{1}$ State Key Laboratory of Palaeobiology and Stratigraphy, Center for Excellence in Life and Palaeoenvironment, Nanjing Institute \\ of Geology and Palaeontology, Nanjing, China \\ ${ }^{2}$ Institute of Geology, Shandong Institute of Geological Survey, Jinan, China \\ ${ }^{3}$ Institute of Geology, Czech Academy of Sciences, Prague, Czech Republic \\ Email: *gangli@nigpas. ac.cn
}

How to cite this paper: $\mathrm{Li}, \mathrm{G}$., $\mathrm{Xu}, \mathrm{K} . \mathrm{M}$., Ning, Z.G., Schnabl, P., Li, X., Zhang, Z.G., Qin, J., Huang, Y.B. and Guo, J. (2019) Preface: Cretaceous Earth Dynamics and Climate in Asia. Open Journal of Geology, 9, 539-542.

https://doi.org/10.4236/ojg.2019.910036

Received: August 30, 2019

Accepted: September 17, 2019

Published: September 20, 2019

Copyright $\odot 2019$ by author(s) and Scientific Research Publishing Inc. This work is licensed under the Creative Commons Attribution International License (CC BY 4.0).

http://creativecommons.org/licenses/by/4.0/
Since the industrial revolution, the increasing usage of fossil energy by humans has led to a continuous increase in atmospheric $\mathrm{CO}_{2}$ emissions, thereby disrupting and unbalancing the global carbon cycle [1]. The direct result is a very rapid global warming. We are now experiencing its likely effects, such as the waning of pole ice caps, rising sea levels, regional changes in precipitation, acidification of the ocean, more frequently extreme weather events (such as heat waves), and expansion of deserts. The development of human civilization urgently requires us to acquire a deeper understanding of the development trend of this rapid climate change and its environmental effects, a topic that in recent years has become a hot issue of common concern from the general public to the scientific community [2] [3].

The Asian continent offers unique opportunities for studying the Cretaceous greenhouse climate and ecosystems. A variety of environments resulted in diverse ecosystems on land and in the oceans. Cretaceous marine strata of the eastern Tethys (India and Tibet of China) and the western Pacific (Japan, South Korea, China and Russia) open an indispensable window for the study of the oceanic anoxic events, oceanic oxygen-rich events and rapid climate changes [4] [5] [6]. Cretaceous continental deposits in Asia [7] [8] [9] [10] contain abundant terrestrial organisms that witness the ecosystem evolution and significant rapid climate changes [11] [12] [13].

Various Cretaceous terrestrial lithologic records and large igneous provinces in Asia bear witness to the environmental changes and ecosystem evolution [14] [15]. Cretaceous pedogenic carbonates of paleosols and fossil leaf stomatal index quantitatively depicted the fluctuation and evolutionary trends of the atmospheric $\mathrm{CO}_{2}$ levels [16]. Desert deposits in the interior regions of the continent (Mongolia, China, and Thailand) reveal the shift of subtropical high-pressure belt and dramatic changes in climatic zonation pattern in Asia [17]. 
In this special issue, there are 50 short research papers covering a broad spectrum of fields reflecting many facets of biodiversity, palaeoenvironment, palaeogeography and palaeoclimate from the marine and non-marine Cretaceous sequences in Asia. The special issue is divided into four sections: 1) new research results on fossil records in the marine Cretaceous deposits in Asia provide important taphonomic [18], palaeogeographic and palaeoecological information which are useful for inter-continental, marine and non-marine biostratigraphic correlation [19] [20], and palaeoceanographic and palaeoenvironmental reconstruction; 2) new research results on Cretaceous non-marine fossil records provide the information of the palaeogeography, palaeoecology and palaeoclimate on land in Asia and South America, including a discussion on the origin of angiosperm [21], the turnover of fossil flora and faunas, and the description of new dinosaur taxa; 3 ) the overview of progress in the Cretaceous stratigraphy in China, Malaysia, Pakistan, the Far East of Russia, Thailand and Vietnam, especially including a discussion on the new stratigraphic framework in Shandong province [22], and the new progress on the Jurassic/Cretaceous and Cretaceous/Paleogene boundaries in China; 4) Cretaceous palaeoclimate reconstruction based on evidence from fossil records, special lithology and palaeo-weathering index. The Late Cretaceous floral turn-over in the Indian subcontinent indicates a latitudinal shifting of the Indian plate from sub-tropical to tropical zone during the Maastrichtian [23]. A palaeoweathering analysis of claystone samples intercalated within the mid-Cretaceous aeolian sandstone indicates that an alternate pluvious/arid paleoclimate controls the Sichuan basin during the mid-Cretaceous [24]. Aeolian deposits documented in the Santai Formation in the Mengyin Basin may indicate a change in palaeowind regime during the Late Jurassic to Early Cretaceous time interval [25]. The four sections of the special issue are topically overlapping and closely linked. They demonstrate a new exciting start of the UNESCO-IUGS IGCP Project 679 .

\section{Acknowledgements}

We are sincerely grateful for the critical reviews of all referees who helped to improve the manuscripts included in the present volume. The study was supported by the Strategic Priority Research Program of the Chinese Academy of Sciences (XDB26000000) and the National Natural Science Foundation of China (41572006, 41688103, 41972007). This is a contribution to UNESCO-IUGS IGCP Project 679.

\section{Conflicts of Interest}

The authors declare no conflicts of interest regarding the publication of this paper.

\section{References}

[1] Li, G., Hu, X.M., Koutsoukos, E.A.M. and Huang, Y.J. (2016) Research on the Cre- 
taceous Greenhouse World in China. Cretaceous Research, 62, 95-97. https://doi.org/10.1016/j.cretres.2016.02.011

[2] Hay, W.W. (2011) Can Humans Force a Return to a "Cretaceous" Climate? Sedimentary Geology, 235, 5-26. https://doi.org/10.1016/j.sedgeo.2010.04.015

[3] Wang, C.S. (2013) Environmental/Climate Change in the Cretaceous Greenhouse World: Records from Terrestrial Scientific Drilling of Songliao Basin and Adjacent Areas of China. Palaeogeography, Palaeoclimatology, Palaeoecology, 385, 1-5. https://doi.org/10.1016/j.palaeo.2013.05.006

[4] Hu, X.M., Wang, C.S., Scott, R.W., Wagreich, M. and Jansa, L. (2009) Cretaceous Oceanic Red Beds: Stratigraphy, Composition, Origins and Paleoceanographic and Paleoclimatic Significance. SEPM Special Publication Vol. 91, 1-276. https://doi.org/10.2110/sepmsp.091

[5] Takashima, R., Nishi, H., Yamanaka, T., Hayashi, K., Waseda, A., Ovuse, A., Tomosugi, T., Deguchi, N. and Mochizuki, S. (2010) High-Resolution Terrestrial Carbon Isotope and Planktic Foraminiferal Records of the Upper Cenomanian to the Lower Campanian in the Northwest Pacific. Earth Planetary Science Letter, 289, 570-582. https://doi.org/10.1016/j.epsl.2009.11.058

[6] Wang, C.S., Hu, X.M., Huang, Y.J., Wagreich, M., Scott, R. and Hay, W. (2011) Cretaceous Oceanic Red Beds as Possible Consequence of Oceanic Anoxic Events. Sedimentary Geology, 235, 27-37. https://doi.org/10.1016/j.sedgeo.2010.06.025

[7] Sha, J.G. (2007) Cretaceous Stratigraphy of Northeast China: Non-Marine and Marine Correlation. Cretaceous Research, 28, 146-170.

https://doi.org/10.1016/j.cretres.2006.12.002

[8] Ando, H., Hasegawa, H., Hasegawa, T., Ohta, T., Yamanoto, M., Hasebe, N., Li, G. and Ichinnorov, N. (2011) Jurassic-Cretaceous Lacustrine Deposits in East Gobi Basin, Southeast Mongolia. Journal of the Geological Society of Japan, 111, 11-12. https://doi.org/10.5575/geosoc.117.11.XI XIII

[9] Hasegawa, H., Ando, A., Hasebe, N., Ichinnorov, N., Ohta, T., Hasegawa, T., Yamanoto, M., Li, G., Erdenetsogt, B.O., Heimhofer, U., Murata, T., Shinya, H., Enerel, G., Oyunjargal, G., Munkhtsetseg, O., Suzuki, N., Irino, T. and Yamanoto, K. (2018) Depositional Ages and Characteristics of Middle-Upper Jurassic and Lower Cretaceous Lacustrine Deposits in Southeastern Mongolia. Island Arc, 27, e12243. https://doi.org/10.1111/iar.12243

[10] Xi, D.P., Wan, X.Q., Li., G.B. and Li, G. (2019) Cretaceous Integrative Stratigraphy and Timescale of China. Science China Earth Sciences, 62, 256-286. https://doi.org/10.1007/s11430-017-9262-y

[11] Zhou, Z.H., Barrett, P.M. and Hilton, J. (2003) An Exceptionally Preserved Lower Cretaceous Ecosystem. Nature, 421, 807-814. https://doi.org/10.1038/nature01420

[12] Chen, P.J., Li, G. and Batten, D.J. (2007) Evolution, Migration and Radiation of Late Mesozoic Conchostracans in East Asia. Geological Journal, 42, 391-413. https://doi.org/10.1002/gj.1064

[13] Li, G., Shen, Y.B. and Batten, D.J. (2007) Yanjiestheria, Yanshania and the Development of the Eosestheria Conchostracan Fauna of the Jehol Biota in China. Cretaceous Research, 28, 225-234. https://doi.org/10.1016/j.cretres.2006.07.002

[14] Paik, I.S., Huh, M., So, Y.H., Lee, J.E. and Kim, H.J. (2007) Traces of Evaporites in Upper Cretaceous Lacustrine Deposits of Korea: Origin and Paleoenvironmental Implications. Journal of Asian Earth Sciences, 30, 93-107.

https://doi.org/10.1016/j.jseaes.2006.07.013 
[15] Chenet, A.L., Courtillot, V., Fluteau, F., Gerard, M., Quidelleur, X., Khadri, S.F.R., Subbarao, K.V. and Thordarson, T. (2009) Determination of Rapid Deccan Eruptions across the Cretaceous-Tertiary Boundary Using Palaeomagnetic Secular Variation: 2. Constraints from Analysis of Eight New Sections and Synthesis for a 3500-m-Thick Composite Section. Journal of Geophysical Research, 114, B06103. https://doi.org/10.1029/2008JB005644

[16] Wang, Y.D., Huang, C.M., Sun, B.N., Quan, C., Wu, J.Y. and Lin, Z.C. (2014) Paleo- $\mathrm{CO}_{2}$ Variation Trends and the Cretaceous Greenhouse Climate. Earth-Science Reviews, 129, 136-147. https://doi.org/10.1016/j.earscirev.2013.11.001

[17] Hasegawa, H., Tada, R., Jiang, S., Suganuma, Y., Imsamut, S., Charusiri, P., Ichinnorov, N. and Khand, Y. (2012) Drastic Shrinking of the Hadley Circulation during the Mid-Cretaceous Supergreenhouse. Climate of the Past, 8, 1323-1337. https://doi.org/10.5194/cp-8-1323-2012

[18] Ando, H. (2019) Taphonomy and Sedimentological Significance of Oyster Shell Beds within Cretaceous Transgressive Sediments in Japan. Open Journal of Geolology, 10, 547-550. https://doi.org/10.4236/ojg.2019.910038

[19] Li, G. and Bengtson, P. (2019) The Key Role of Aptian-Albian Marine Fossils from Eastern Heilongjiang in Marine-Nonmarine Stratigraphic Correlation. Open Journal of Geology, 10, 543-546. https://doi.org/10.4236/ojg.2019.910037

[20] Matsuoka, A., Ito, T. and Sakai, Y. (2019) Land-Ocean Linkage: Pelagic Cherts in Mesozoic Neritic-Terrestrial Sequences in East Asia. Open Journal of Geology, 10, 551-553. https://doi.org/10.4236/ojg.2019.910039

[21] Wang, X. (2019) Origin of Angiosperms and Their Diversification in the Cretaceous. Open Journal of Geology, 10, 577-580. https://doi.org/10.4236/ojg.2019.910046

[22] Liu, Y.Q., Kuang, H.W., Xu, K.M., Ning, Z.G., Peng, N., Du, S.X. and Chen, J. (2019) The Cretaceous of Shandong Province. Open Journal of Geology, 10, 646-649. https://doi.org/10.4236/ojg.2019.910064

[23] Prasad, V. (2019) Late Cretaceous Climate of the Indian Subcontinent. Open Journal of Geology, 10, 692-695. https://doi.org/10.4236/ojg.2019.910077

[24] Cho, T., Mantani, H., Ohta, T. and Li, G. (2019) Evaluation of Cretaceous Hinterland Weathering and Climate in the Sichuan Basin, SW China. Open Journal of Geology, 10, 696-699. https://doi.org/10.4236/ojg.2019.910078

[25] Xu, H., Liu, Y.Q., Kuang, H.W., Peng, N., Xu, K.M. and Chen, J. (2019) Late Jurassic-Early Crtaceaou Erg Deposits in the Mengyin Basin, Western Shandong Province, China: Inferences about the Wind Rgime and Paleogeography. Open Journal of Geology, 10, 700-703. https://doi.org/10.4236/ojg.2019.910079 